\title{
A Review of Nosema cerane and Nosema apis: Caracterization and Impact for Beekeeping
}

\author{
Claudia PAȘCA ${ }^{1}$, Liviu Alexandru MĂRGHITAȘ ${ }^{1}$, Cristinel ȘONEA², Otilia BOBIŞ ${ }^{3}$, \\ Ioana Adriana BUZURA-MATEI ${ }^{4}$ and Daniel Severus DEZMIREAN ${ }^{1 *}$ \\ ${ }^{1}$ Faculty of Animal Science and Biotechnologies, University of Agricultural Sciences and Veterinary \\ Medicine Cluj-Napoca, 3-5 Mănăștur Str., 400372, Cluj Napoca, Romania \\ ${ }^{2}$ Faculty of Economic Sciences, University of Valahia, Târgoviște, România \\ ${ }^{3}$ Life Science Institute "King Michael I of Romania, University of Agricultural Sciences and Veterinary \\ Medicine Cluj-Napoca, 3-5 Mănăștur Str., 400372, Cluj Napoca, Romania \\ ${ }^{4}$ Faculty of Veterinary Medicine,University of Agricultural Sciences and Veterinary Medicine Cluj-Napoca, \\ 3-5 Mănăștur Str., 400372, Cluj Napoca, Romania \\ *corresponding author: ddezmirean@usamvcluj.ro
}

Bulletin UASVM Animal Science and Biotechnologies 76(2)/ 2019

Print ISSN 1843-5262; Electronic ISSN 1843-536X

DOI:10.15835/buasvmcn-asb: 0018.19

\begin{abstract}
Two microsporidia have been described infecting honey bees worldwide: Nosema apis and Nosema ceranae. The infecting forms of the parasite are the spores, ingested by the adult host insects. Studies demonstrated that the infection with Nosema spp. range from less than 1 to 100 percent, this disease reduces worker longevity by $22-44 \%$ which in turn reduces honey production and causes incomplete crop pollination. However, the used conventional drugs in beekeeping sector has a strong limitation due to the big concern about antibiotics resistance, transmission of antibiotics residues in beehive products and to a lesser extent, unbalancing risk of bee gut microbiota.This review highlights the importance to have healthy bee colonies, which implicitly lead to safety bee products. For this reason, orientation towards alternative treatments without antibiotics and based on natural products with higher antimicrobial effects it is very topical.
\end{abstract}

Keywords: Apis mellifera, nosemosis, bee products, treatments, beekeeping

\section{Introduction}

Nosemosis is one of the most serious diseases of adult honey bees occurring in nearly every country with beekeeping practices and it negatively decreases productivity and survival of honeybee colonies (Botias et al., 2013; Huang, 2012), colony depopulation and collapse (Paxton, 2010) by affecting the development of the fatprotein body as well as the levels of proteins and fatty acids in the bee haemolymph (Chen et al., 2009; Gajger et al. 2009), Nosemosis can reduce worker longevity by $22 \%$ to $44 \%$ (Kang et al., 1976; Aydin et al, 2006; Lotfi et al., 2009), which in turn reduces honey production and causes incomplete crop pollination (Forsgren and Fries, 2003; Fries et al, 2003). The infection has two forms: the parasite multiply inside the cells of intestinal epithelium of honeybees (vegetative form) and another with a reduced metabolism usually it found in dead honeybees or when its eliminated in the outer environment (sporulated form) (Mărghitaș, 2017). and Based on molecular phylogenies, the microsporidia are included into the Opisthokonta rank, Fungi kingdom, Microsporidia phylum, Dihaplophasea class, Dissociodihaplophasida order, Nosematidae family, Nosema genus, Nosema apis and Nosema ceranae species. Microsporidia are, thus, to be regarded as highly specialized parasitic fungi (Sina et al., 2005). Nosema contains more than 150 species, most of them infects invertebrate hosts (Higes et al., 2007; Aurori et al., 2011) causing some 
well known diseases such as pebrine disease in silkworms (by Nosema bombycis) and dysentery in honeybees (by Nosema apis). In Romania, both species (N. apis and N. ceranae) exists in Apis mellifera colonies (Dumitru et al., 2017).

The purpose of the present review is to describe the two bee parasitic forms: $N$. apis and $N$. ceranae and their impact for beekeeping, Also, the use of medicinal plants with therapeutic effects for prevent or treat nosemosis in bee colonies is described and encouraged.

\section{Nosema apis \& Nosema ceranae}

The most common forms of Nosema spp in bees are: Nosema apis (Zander, 1909) and Nosema ceranae (Fries et al. 1996). N. apis is one of the first described microsporidian parasite and believed to be the only etiological agent of Nosemosis in the European honeybee (Apis mellifera) which can decrease worker longevity and cause considerable winter colony losses (Fries, 1993; Higes et al., 2006; Williams et al., 2008a; Szawarski et al., 2019). The size of $N$. apis spores lies between 5-7 and 3-4 $\mu \mathrm{m}$ (Utuk et al., 2016). Chioveanu et al. (2004) described the factors which determine the appearance of this disease, such as: the climate (the sudden variations of temperature, long and cold winters), the inappropriate higiene of the beehive, some associated diseases such as amoebiasis and storage on winter period in the hive black color honey, rich in minerals, which may cause bee diarrhea.

Whilst $N$. ceranae originates from Asia and was originally described as a pathogen of the Asian cavity nesting bee A. cerana (Fries et al.,1996) and it has been introduced into European honeybees within the last few decades (Higes et al., 2006; Martín-Hernández et al., 2007; Klee et al., 2007; Paxton et al., 2007; Chen et al., 2008; Williams etal., 2008a; Invernizzi et al., 2009; Currie et al., 2010; Botías et al., 2011). Studies show that $N$. ceranae may be more virulent than $N$. apis when infecting A. mellifera, and colony depopulation and collapse in warmer areas of Europe, has been reported (Higes et al., 2008a), but not in northern parts of Europe (Gisder et al., 2010a), in North America (Guzman-Nova, 2010; Williams et al., 2010a) or in South America (Invernizzi et al., 2009). The spores of $N$. ceranae dimensions are between $4.4 \times 2.2 \mu \mathrm{m}$ (Utuk et al., 2016).
The germination spores capacity and the Nosemosismultiplication dependsessentiallyontemperature, i.e. $30^{\circ}-35^{\circ} \mathrm{C}\left(\mathrm{N}\right.$. apis), in winter and over $35^{\circ} \mathrm{C}$ (N. ceranae), during summer. N. ceranae spores can survive the frost, unlike $N$. apis.

Chemurot et al. (2017) describe a new microsporidian, Nosema neumanni n. sp., detected in some colonies in Uganda in addition to the known $N$. apis and N. ceranae. There are clear differences in the ultra-structural and molecular characteristics of the new mentioned Nosema specie, the spores are smaller under the TEM and the number of polar filament coils is between 10 and 12, compared to 20-23 for $N$. ceranae and more than 30 often seen in N. apis (Fries et al. 1996).

Interestingly, that some authors (Alaux et al., 2010; Martin-Hernandez et al., 2011; Vidau et al., 2011) have described that $N$. ceranae can produce changes in the glucidic metabolism on honeybees. The explanations are that the infected worker appear to be unable to use the consumed excess of carbohydrates, because most of them are "forced" by the pathogen to complete its life cycle (Mayack and Nang, 2013).

Hence, the mechanisms controlling the mobilization of energy reserves appear to be disturbed and there is poor carbohydrate homeostasis in their haemolymph (Aliferis et al., 2012). The stronger sugar demand and higher consumption could be a host response to the infection, directly related to the dependence of microsporidia on host energy. However, the intestinal lesions caused by $N$. ceranae proliferation may decrease the digestive capacity of honey bees and generate signs of starvation, such as impoverishment of hypopharyngeal protein secretions in nurse bees (Vidau et al., 2014).

Additionally, Li et al. (2018) reported that bees infected by $N$. ceranae show an accelerated lipid loss, suggesting lipids that may be used also as a fuel for increased metabolic demands due to the infections.

Today Nosemosis is a worldwide disease present in every beekeeping country (Table 1.), although according to the OIE statistics, the parasite is spread in $43 \%$ of the countries having bee colonies. Thus, Table 1. represent the spreading of Nosema spp. infection worldwide, based on molecular analysis by the quoted authors. 
Table. 1. Nosema spp. incidence infection in honey bee populations worldwide reported in scientific publications

\begin{tabular}{|c|c|c|c|c|}
\hline Host & Year & $\begin{array}{l}\text { Region and/or } \\
\text { Country }\end{array}$ & Nosema species & References \\
\hline \multicolumn{5}{|c|}{ Asia } \\
\hline A. ceranae & 1996 & China & N.ceranae & Fries et al., 1996 \\
\hline $\begin{array}{l}\text { A. ceranae, } A \text {. } \\
\text { melifera }\end{array}$ & $1992,2007-2008$ & China, Japan, Taiwan & N. ceranae, N. apis & Chen et al., 2009 \\
\hline A. mellifera & 2009 & Japan & N. ceranae & $\begin{array}{l}\text { Yoshiyama and } \\
\text { Kimura, } 2011\end{array}$ \\
\hline A. mellifera & n.a. & Jordan & N. ceranae & Haddad, 2014 \\
\hline A. mellifera & 2017 & Saudi Arabia & Nosema spp. & Ansari et al., 2017 \\
\hline $\begin{array}{l}\text { A. ceranae, } A \text {. } \\
\text { mellifera }\end{array}$ & 2006 & Vietnam & N.ceranae & Klee et al., 2007 \\
\hline $\begin{array}{l}\text { A. ceranae, } A \text {. } \\
\text { mellifera }\end{array}$ & 2008-2009 & Thailand & N.ceranae & $\begin{array}{l}\text { Chaimanee et al., } \\
2010\end{array}$ \\
\hline \multirow[t]{2}{*}{ A. mellifera } & $2005-2006$ & Turkey & N.apis & $\begin{array}{l}\text { Whitaker et al., } \\
2011\end{array}$ \\
\hline & 2007-2009 & Turkey & N.ceranae & Muz et al., 2010 \\
\hline \multicolumn{5}{|c|}{ Northern Europe } \\
\hline A. mellifera & 1988-2006 & Denmark & N.apis, N.ceranae & Klee et al., 2007 \\
\hline \multirow{3}{*}{ A. mellifera } & 1986-1995 & Finland & N.apis & Paxton et al., 2007 \\
\hline & $1998,2002,2006$ & Finland & N.apis, N. ceranae & Paxton et al., 2007 \\
\hline & 2006 & Finland & N. ceranae & Klee et al., 2007 \\
\hline \multirow{3}{*}{ A. mellifera } & $1998,2003,2005$ & Sweden & N.apis & Klee et al., 2007 \\
\hline & 2006 & Sweden & N.apis, N.ceranae & Klee et al., 2007 \\
\hline & n.a. & Sweden & Nosema spp. & Fries , 2010 \\
\hline A. mellifera & $2011-2014$ & Lithuania & N. ceranae, N.apis & $\begin{array}{c}\text { Blazyte-Cereskiene } \\
\text { et al., } 2016\end{array}$ \\
\hline \multicolumn{5}{|c|}{ Eastern Europe } \\
\hline \multirow[t]{2}{*}{ A. mellifera } & 2014-2016 & Ukraine & N.apis, N. cerane & Odnosum , 2017 \\
\hline & & Central Europe & & \\
\hline \multirow[t]{2}{*}{ A. mellifera } & $2003,2005-2006$ & Germany & N. cerane, N.apis & $\begin{array}{c}\text { Martin-Hernandez } \\
\text { et al., 2007; Klee et } \\
\text { al., } 2007\end{array}$ \\
\hline & $2005-2016$ & Gemany & N. cerane, N.apis & Gisder et al., 2017 \\
\hline \multirow{3}{*}{ A. mellifera } & 1994 & Hungary & N. apis & Klee et al., 2007 \\
\hline & $2006-2007$ & Hungary & N. ceranae, N.apis & $\begin{array}{c}\text { Tapaszti et al., } \\
2009\end{array}$ \\
\hline & 2017 & Hungary & Nosema spp. & $\begin{array}{c}\text { Sapcaliu et al., } \\
2017\end{array}$ \\
\hline \multirow{2}{*}{ A. mellifera } & 2006 & Switzerland & N. ceranae, N.apis & $\begin{array}{c}\text { Martin-Hernandez } \\
\text { et al., } 2007\end{array}$ \\
\hline & 2011 & Switzerland & N. ceranae & $\begin{array}{c}\text { Tritscheler et al., } \\
2017\end{array}$ \\
\hline \multirow{3}{*}{ A. mellifera } & & Western Europe & & \\
\hline & $2002-2005$ & France & N. ceranae, N. apis & $\begin{array}{c}\text { Chauzat et al., } \\
2007\end{array}$ \\
\hline & 2006 & France & N. ceranae, N. apis & $\begin{array}{c}\text { Martin-Hernandez } \\
\text { et al., } 2007\end{array}$ \\
\hline
\end{tabular}




\begin{tabular}{|c|c|c|c|c|}
\hline A. mellifera & 2005 & Ireland & N. apis & Klee et al., 2007 \\
\hline A. mellifera & 2007-n.a. & England & N. apis, N. ceranae & Budge , 2008 \\
\hline A. mellifera & $2001,2005-2006$ & UK (Norther a Ireland) & N. apis & Klee et al., 2007 \\
\hline \multicolumn{5}{|c|}{ Southeastern Europe } \\
\hline A. mellifera & 2006-2009 & Fyrom & N. ceranae & $\begin{array}{c}\text { Stevanovic et al., } \\
2011\end{array}$ \\
\hline A. mellifera & 2006-2009 & $\begin{array}{l}\text { Bosnia and } \\
\text { Herzegovina }\end{array}$ & N. ceranae & $\begin{array}{l}\text { Stevanovic et al., } \\
2011\end{array}$ \\
\hline A. mellifera & 2017 & Bulgaria & N. ceranae & $\begin{array}{l}\text { Shumakova et al., } \\
2018 \\
\end{array}$ \\
\hline A. mellifera & $2006-2009$ & Montenegro & N.ceranae & $\begin{array}{c}\text { Stevanovic et al., } \\
2011 \\
\end{array}$ \\
\hline A. mellifera & 2015 & Romania & N. ceranae & $\begin{array}{c}\text { Mederle et al., } \\
2018 \\
\end{array}$ \\
\hline \multirow{2}{*}{ A. mellifera } & 2006 & Serbia & N. ceranae & Klee et al., 2007 \\
\hline & $\begin{array}{c}\text { 2000-2005, 2006- } \\
2009\end{array}$ & Serbia & N. ceranae & $\begin{array}{l}\text { Stevanovic et al., } \\
2011 \\
\end{array}$ \\
\hline \multicolumn{5}{|c|}{ Southen Europe } \\
\hline A. mellifera & $2005-2006$ & Greece & N. ceranae & Klee et al., 2007 \\
\hline \multirow{4}{*}{ A. mellifera } & 1993, 1998, 2010 & Italy & N. ceranae, N. apis & $\begin{array}{l}\text { Ferroglio et al., } \\
2013 \\
\end{array}$ \\
\hline & 1994 & Italy & N.apis & Klee et al., 2007 \\
\hline & $2005-2006$ & Italy & N.ceranae & Klee et al., 2007 \\
\hline & 2014-2015 & Italy & N. ceranae & Papini et al., 2017 \\
\hline A. mellifera & $\begin{array}{c}2004-2005,2005- \\
2006\end{array}$ & Spain & N. apis, N. ceranae & $\begin{array}{c}\text { Higes et al., 2006; } \\
\text { Martin-Hernandez } \\
\text { et al., 2007; Klee et } \\
\text { al., } 2007\end{array}$ \\
\hline \multicolumn{5}{|c|}{ North America } \\
\hline A. mellifera & $2008,2010,2012$ & Canada & N.ceranae, N.apis & Emsen et al., 2016 \\
\hline A. mellifera & $2006-2007$ & $\begin{array}{l}\text { Maritime Provinces of } \\
\text { Canada and Minnesota }\end{array}$ & Nosema spp. & $\begin{array}{c}\text { Williams et al., } \\
2008 \mathrm{a}\end{array}$ \\
\hline \multirow{2}{*}{ A. mellifera } & $1995-2007$ & USA & N.ceranae & $\begin{array}{l}\text { Chen et al., 2008; } \\
\text { Klee et al., } 2007\end{array}$ \\
\hline & 2009 & USA & Nosema spp. & $\begin{array}{c}\text { Traver and Fell, } \\
2011 \\
\end{array}$ \\
\hline \multicolumn{5}{|c|}{ South America } \\
\hline \multirow{2}{*}{ A. mellifera } & 2006 & Brazil & N. ceranae & Klee et al., 2007 \\
\hline & $2009-2012$ & Brazil & Nosema spp. & Teixeira et al., 2013 \\
\hline A. mellifera & 2010-2012 & Chile & N. ceranae & $\begin{array}{c}\text { Martinez at al., } \\
2012 \\
\end{array}$ \\
\hline A. mellifera & $1995-1996$ & Mexico & N. ceranae & $\begin{array}{c}\text { Guerrero-Molina et } \\
\text { al., } 2016\end{array}$ \\
\hline A. mellifera & $\begin{array}{c}1990,2004,2007- \\
2008\end{array}$ & Uruguay & N. ceranae & $\begin{array}{l}\text { Invernizzi et al., } \\
2009 \\
\end{array}$ \\
\hline \multicolumn{5}{|c|}{ Africa } \\
\hline A. mellifera & 2014-2015 & Uganda & $\begin{array}{l}\text { N. ceranae, N.apis, } \\
\text { N. neumanni }\end{array}$ & $\begin{array}{l}\text { Chemurot et al., } \\
2017 \\
\end{array}$ \\
\hline \multicolumn{5}{|c|}{ Oceania } \\
\hline A. mellifera & 2007-2008 & Australia & N.apis, N. ceranae & Giersh et al., 2009 \\
\hline A. mellifera & 2006 & New Zeland & N. ceranae, N.apis & Klee et al., 2007 \\
\hline
\end{tabular}




\section{How is Nosema spp. transmitted?}

Nosema is transmitted through the ingestion of spores via contaminated water or food, through the exchange of food between bees or when they perform their cleaning duties (Ptaszyñska et al., 2012; Martin-Hernandez et al., 2018; Odemer et al., 2018). Nosemosis infections are transmitted horizontally among bees, by ingestion of spores from the environment. For example, housecleaning bees, on removing nosema-infected bee feces deposited in the hive, material with infective spores, from infected worker honeybees. Thus, trophallaxis may be an important transmission pathway from bee to bee, or from colony to colony, because infected bees can contaminate beekeeping material when they are crushed during hive manipulation (Higes et al., 2010). Moreover, queens commerce and their worker bee escorts may be a source of infection when they comes from another geographic area (Giersch et al., 2009).

Bee pollen stored in honeycombs is a reservoir of $N$. ceranae spores from the self-contamination during the process of pollen collection (regurgitation, saliva etc.) (Higes et al., 2010).

The median infective dose for $N$. apis has been described to be 94.3 spores per bee (Fries, 1988) whereas for N. ceranae it was established in 149 spores per bee, although the minimum dose capable of causing a detectable infection was 1.28 spores (McGowan et al., 2016). The Nosema infection cycle is well understood. Spores are ingested by the honeybees and germinate quickly in the midgut (Odemer et al., 2018). The spores extrude the polar tube and penetrates in the epithelial cells to release the sporoplasm directly into the cytoplasm (Higes et al., 2007; Fries, 2010). Within a week, the host epithelial cells are filled with offspring spores (Graaf et al., 1994; Gisder et al., 2011) and the cells can burst to release a new generation of primary spores. If the honeybees can block the further infection, the primary spores develop into environmental spores and excreted through the feces. Otherwise, primary spores will germinate again and keep infecting more cells. However, the mechanisms of blocking Nosema infection in honey bees are still unclear (Huang et al., 2012).

\section{Bee products}

Bee products are multicomponent natural substances necessary for the proper course of basic life reactions (Bobiș et al., 2010). These include the following: honey, bee pollen, and extracts derived from it, that is, bee bread, propolis, royal jelly, and bee venom (Basim et al., 2006; Mărghitaș, 2017). Bee products demonstrated a wide range of healing effects. They increase the level of ATP, thus neutralize an effect of many toxic agents, increase immunity of an organism, and improve the energy balance of tissues (Kieliszek et al., 2018). Today, consumer interest regarding honey and its derived products is oriented towards organic foods, and if antibiotics are used in bee colonies (like Fumagillin B), which is the only treatment available now on the market that can be used to treat nosemosis, althoug its effectiveness is questionable as it is not effective on the mature spores of Nosema, then this antibiotic can be found in the bee product.Without alternative treatments for Nosema, organic beekeepers will struggle to produce organic bee products, with high losses of the untreated hives. Regarding this, the European Commission establishes that the qualification of organic honey and other bee products as being from organic production is closely bound to the characteristics of hive treatments as well as the quality of the environment (Chiesa et al., 2016). This qualification also depends on the conditions of extraction, processing and storage of bee products. The Council Regulation 1804/1999 EC is very restrictive with regard to the production of organic honey in terms of the origin of bees, siting of the apiaries, feed, disease prevention and veterinary treatments.

\section{Impact of beekeeping practices}

The importance of beekeeping is due, on one hand, to the nutritional and therapeutic value of the products obtained from the practice of this activity (honey, bee pollen, propolis, royal jelly and bee venom), and on the other hand, to the pollination services, because approximately $80 \%$ of the crops are pollinated by bees (Dirina and Bugina, 2012).

The Nosema parasite is ubiquitous, in temperate conditions, Nosemosis being considered to have a serious negative effect on the production capacity of honeybees colonies and the survival capacity of the affected colonies during the winter (Mitrea, 2011; Dumitru et al., 2017).

One of the goals of modern beekeeping is to obtain residue-free bee products, as well as a revival of researches related to using natural products for 
treatment in different pathological conditions. Botias et al. (2012b) and Simeunovic et al. (2014) showed the important role of the queen's age for the bee colonies and they suggested to replaced an old queen by a younger one, for decrease the proportion of Nosema infection in the hive. It was also recently shown that the therapeutic doses of oxalic acid used for Varroa control might inhibit the development of $N$. ceranae in laboratory and field conditions, both at the individual and colony levels (Nanetti et al., 2015). There is also some evidence that formic acid fumigation may help to suppress Nosema (Underwood and Currie, 2009). Moreover, Costa et al. (2010) reported that thymol and coumaphos used against Varroa can be suspected to increase susceptibility to infection by N. ceranae.

Over the years of confronting nosemosis, much effort has been invested in searching effective cure against this. So far, bicyclohexylammonium fumagillin, an antibiotic isolated from the fungus Aspergillus fumigatus, is one of the few drugs known to be active against microsporidia (McCowen et al., 1951), suppressing their reproduction and multiplication at recommended concentrations (Higes et al., 2011; Huang et al., 2013).

Fumagillin is extensively used to control Nosema disease in apiculture for over 60 years and inhibits the enzyme methionine aminopeptidase-2 (MetAP2) activity (Martín-Hernández et al., 2012). In the commercial formulation, fumagillin is present as a salt in an equimolar quantity with dicyclohexylamine (DCH).

Mutinelli (2003) described a protocol for the application of fumagillin against Nosema apis. This protocol assume an mix $100 \mathrm{mg}$ of fumagillin to 1 gallon of sugar syrop (mix 2 parts sugur to 1 part water). Unfortunately, the toxicity of fumagillin can caused different illness for humans due to the remanence of residues in hive products (van den Heever et al., 2014). For this reason fumagillin is no longer avaible on the EU market since January $1^{\text {st }}, 2000$ (van den Heever et al., 2016a). Also, the fumagillin treatment is prohibited in US and Israel during the foraging season and it is commonly prophylactically applied to the hives in late fall and early spring in most of the US and Canada (Huang et al., 2013; Williams et al., 2011) or in NovemberDecember in Israel.

It has also been reported that $N$. ceranae seems to reproduce even better at lower concentrations of fumagillin, which also affects the bees' physiology, such that its use may augment the prevalence of $N$. ceranae (Huang et al., 2013). Risks related to the use of antibiotics for the control of honeybee diseases are persistence of the infection, reappearance of the disease and honey contamination (Directive 86/23/CE and further amendments)

Several semisynthetic and synthetic fumagillin analogues were shown to possess biological activity against $N$. ceranae under laboratory conditions but none were as effective as Fumagillin-BVR (van den Heever et al., 2016a). Finally, a promising assay has shown that the administration of autoclaved spores to larvae was able to reduce the infection levels of adults by $57 \%$ without significantly altering larval or adult longevity (Endler, 2014).

\section{Natural products}

However, currenttrends offer greatimportance to the antimicrobial effects that some natural products can have on bee colonies (Table.2.). The most popular alternative treatments against nosemosis in Europe are Api Herb, Nozevit, Vita Feed Gold, Protofil, Hive Alive and Nosestat. Gajger et al. (2009) has demonstrated Nozevit treatment in comparison with non-treated bee colonies, a considerable reduction in spores: $48.73 \%$ on $10^{\text {th }}$ day; $50.46 \%$ on $15^{\text {th }}$ day and $70.91 \%$ on $22^{\text {nd }}$ day after artificial infection with $N$. apis spores. Another study on nutraceutical, prebiotic and probiotics showed that acacia gum as the most effective prebiotic, although had a high mortality as side effect, and the probiotic Protexin ConcentrateVC single-strain (ProtexinC1) as able to reduce the spores, increasing the bee survival (Borges, 2015).

In Romania, Chioveanu et al. (2004) has tested the efficacy of Protofil in two apiaries between 1999-2002 and as after 10 series of administration, the therapeutic effect of the medicine assessed on the basis of the laboratory exam was: apiary I - 74\% and apiary II -89\%. Dumitru et al. (2017) have tested a mixture of medicinal herbs and etheric oils obtained from melliferous plants against Nosemosis and verified the toxicological effects for honeybees.

Ptaszyńska etal. (2017) demonstrated that the PP(Asp)2 don't have adverse effects on honeybee lifespan and the introduction of PP(Asp) 2 into the diet of nosemosis-infected honeybees resulted in significant reduction $(F=19.212$ and $\mathrm{p}=0.022$ on day 12) in the number of Nosema spores, for 
Table. 2. Natural products effectiveness used in preventing or treating Nosema spp.

\begin{tabular}{|c|c|c|c|}
\hline Natural products & N.apis & N.ceranae & References \\
\hline Artemisia absinthium L. extract & $\mathrm{X}$ & & Pohorecka, 2004 \\
\hline Protofil & $\mathrm{X}$ & & Chioveanu et al., 2006 \\
\hline Natural Essential Oils & $\mathrm{X}$ & $\mathrm{X}$ & Dumitru et al., 2017 \\
\hline Propolis extract & & $\mathrm{X}$ & Suwannapong et. al., 2018 \\
\hline $\begin{array}{l}\text { Commercial probiotics } \\
\text { and prebiotics }\end{array}$ & & $\mathrm{X}$ & Ptaszyńska et al., 2016 \\
\hline Nozevit & $\mathrm{X}$ & & Gajger et al., 2009 \\
\hline TMePyP and PP(Asp)2 Porphyrins & & $\mathrm{X}$ & Ptaszyńska et al., 2017 \\
\hline $\begin{array}{l}\text { Laurel, Origanum, Rosemary, Cinnamon and } \\
\text { Eucalypt essential oils }\end{array}$ & & $\mathrm{X}$ & Porrini et al., 2017 \\
\hline
\end{tabular}

this reason we consider that the prophyrins are promising alternatives to conventional antibiotics.

\section{Conclusion}

The sudden changes of the temperature, late spring, raining autumn, bad food, matures of aged bees are a few factors which can induce the Nosemosis in the apiary, therefore the present study intends to contribute to highlight the importance of implementing prevention, treatment and control measures of honeybees Nosemosis and using the natural products based on medicinal plants. Modern trends concerning consumer's behavior and needs set the directions for the development of new products and thus new technology for their production. In this conditions of an organic beekeeping, natural products based on plant extracts can be an alternative to control of honeybees'diseases; by using of these products can be also avoided risks of drug residues in apiculture products.

Acknowledgments. This work was supported by Program 2: Competitiveness of the Romanian economy through research, development and innovation: PN-III-P2-2.1-CI-2018-1472 nr. $252 \mathrm{CI}$ from 03/09/2018. Project title: Biologically active product for controlling nosemosis in bees.

\section{References}

1. Alaux C, Brunet JL, Dussaubat C, Mondet F, Tchamitchan $S$, Cousin M (2010). Interactions between Nosema microspores and a neonicotinoid weaken honeybees (Apis mellifera). Environ Microbiol, 12:774-782.

2. Aliferis KA, Copley T, Jabaji S (2012). Gas chromatographymass spectrometry metabolite profiling of worker honey bee (Apis mellifera L.) hemolymph for the study of Nosema ceranae infection. J Insect Physiol, 58:1349-1359.

3. Ansari MJ, Al-Ghamdi A, Nuru A, Khan KA, Alattal Y (2017). Geographical distribution and molecular detection of Nosema ceranae from indigenous honey bees of Saudi Arabia. Saudi J. Biol. Sci., 24(5):983-991.

4. Aurori CM, Dezmirean DS, Mărghitas LA, Moritz RFA (2011). Nosema apis and N. ceranae in Western Honeybee (Apis mellifera) - Geographical Distribution and Current Methods of Diagnosis, Bulletin UASVM Animal Science and Biotechnologies, 68(1-2):63-70.

5. Aydin L, Gulegen E, Cakmak I, Girisgin A, Onur W, Harrington (2006). Relation Between Nosema And Chalkbrood Diseases, And Its Implication For An Apiary Management Model. Bull Vet Inst Pulawy, 50:471-475.

6. Basim E, Basim H, Özcan M (2006). Antibacterial activities of Turkish pollen and propolis extracts against plant bacterial pathogens. Journal of Food Engineering, 77(4): 992-996.

7. Blazyte-Cereskiene L, Skrodenytë-Arbaciauskiene V, Radziute S, Nedveckyte I, BudaV (2016), Honey Bee Infection Caused by Nosema spp. in Lithuania. Journal of Apicultural Research, 60(2):77-87.

8. Bobiș O, Marghitas LA, Dezmirean D, Morar O, Bonta V, Chirila F (2010). Quality parameters and nutritional value of different commercial bee products. Bulletin of University of agricultural sciences and veterinary medicine Cluj-Napoca. Animal science and biotechnologies, 67:1-2.

9. Borges D (2015). Control of the intestinal parasite Nosema ceranae in Apis mellifera using nutraceuticals, prebiotics and probiotics. Thesis School of Environmental Sciences. Ontario, Canada: University of Guelph. URL: https://atrium.lib.uoguelph.ca/xmlui/bitstream/ handle/10214/9254/Borges_Daniel_201509_MSc. pdf?sequence53\&isAllowed5y.

10. Botias C, Martin-Hernandez R, Barrios L, Garrido-Bailon E, Nanetti A, Meana A, Higes M (2012b). Nosema spp. parasitization decreases the effectiveness of acaricide strips (Apivar VR) in treating varroosis of honey bee (Apis mellifera iberiensis) colonies. Environ Microbiol Rep, 4:57-65. 
11. Botias C, Martin-Hernandez R, Barrios L, Meana A, Higes M. (2013). Nosema spp infection and its negative effects on honey bees (Apis mellifera iberiensis) at the colony level. Vet Res, 44: 25.

12. Botías C, Martín-Hernández R, Garrido-Bailón E, González Porto A, Martínez-Salvador A, De La Rúa P, Meana A, Higes M (2011). The growing prevalence of Nosema ceranae in honey bees in Spain, an emerging problem for the last decade. Research in Veterinary Sciences 93(1):150-155.

13. Budge G (2008). Nosema ceranae. Bee Craft. January, 7-8.

14. Chaimanee V, Warrit N, Chantawannakul P (2010). Infections of Nosema ceranae in four different honeybee species. J. Invertebr Pathol. 105(2):207-10.

15. Chauzat MP, Higes M, Martín Hernández R, Meana A, Cougoule N, Faucon JP (2007). Presence of Nosema ceranae in Frenchhoney bee colonies. Journal of Apicultural Research, 46(2):127-128.

16. Chemurot M, De Smet L, Brunain M, De Rycker R, De Graaf DC (2017). Nosema neumanni n.sp. (Microsporidia, Nosematidae), a new microsporidian parasite of honeybees, Apis mellifera in Uganda. Eur. J. Protistol., 61:13-19.

17. Chen Y, Evans JD, Smith IB, Pettis JS (2008). Nosema ceranae is a long-present and wide-spread microsporidian infection of the European honey bee (Apis mellifera) in the United States. J. Invertebr. Pathol, 97: 186-188.

18. Chen YP, Evans JD, Murphy C, Gutell R, Zuker M, Gundensen-Rindale D, Jeff PS (2009). Morphological, Molecular, and Phylogenetic Characterization of Nosema ceranae, a Microsporidian Parasite Isolated from the European Honey Bee, Apis mellifera, J. Eukaryot. Microbiol., 56(2):142-147.

19. Chiesa LM, Labella GF, Giorgi A, Panseri S, Pavlovic R, Bonacci S, Arioli F (2016). The occurrence of pesticides and persistent organic pollutants in Italian organic honeys from different productive areas in relation to potential environmental pollution. Chemosphere, 154: 482-490.

20. Chioveanu G, Ionescu D, Mardare A (2004). Control of nosemosis-the treatment with Protofil. Apiacta, 39:31-38.

21. Costa C, Lodesani M, Maistrello L (2010). Effect of thymol and resveratrol administered with candy or syrup on the development of Nosema ceranae and on the longevity of honeybees (Apis mellifera L.) in laboratory conditions. Apidologie, 41: 141-150.

22. COUNCIL REGULATION (EC) No 1804/1999 of 19 July 1999 supplementing Regulation (EEC) No 2092/91 on organic production of agricultural products and indications referring thereto on agricultural products and foodstuffs to include livestock production Official Journal of the European Communities.

23. Currie RW, Pernal SF, Guzman-Novoa E (2010). Honey bee colony losses in Canada. Journal of Apicultural Research 49(1): 104-106.

24. Dirina I, Bugina V (2012). Development assessment of the beekeeping industry in Latvia. Economic Science for Rural Development, 29: 69-76.

25. Dumitru A, Chioveanu G, Ionita M, Dobre G, Mitrea IL (2017). "In Vitro" Studies On Using Natural Essential Oils
In Treatment Of Nosemosis In Honey Bees: Determination Of The Therapeutic Dose, Scientific Works. Series C. Veterinary Medicine. LXIII (2): 2065-1295.

26. Emsen B, Guzman-Novoa E, Hamiduzzaman MM, Eccles L, Lacey B, Ruiz- Pérez RA, Nasr M (2016). Higher prevalence and levels of Nosema ceranae than Nosema apis infections in Canadian honey bee colonies. Parasitol. Res. 115(1):175-81.

27. Endler MB (2014). Feeding larval honey bees (Apis mellifera) dead Nosema spores improves their ability to resist Nosema infection as adults. Thesis in Science.San Diego, CA, USA: University of California. URL https:// escholarship.org/content/qt5x03051g/ qt5x03051g.pdf.

28. Ferroglio E, Zanet S, Peraldo N, Tachis E, Trisciuoglio A, Laurino D, Porporatom (2013). Nosema ceranae has been infecting honey bees Apis mellifera in Italy since at least 1993. J. Apicult. Res., 52:60-61.

29. Forsgren E, Fries I (2003). Acidic Food and Nosema Disease. Proc 38th Int Apic Congr Ljubljana, p .488.

30. Fries I (2010). Nosema ceranae in European honey bees (Apis mellifera). J Invertebr Pathol., 103 (1):S73-79.

31. Fries I (1988). Infectivity and multiplication of Nosema apis $Z$. in the ventriculus of the honey bee (Apis mellifera L.). Apidologie, 19: 319-328.

32. Fries I (1993). Nosema apis - a parasite in the honey bee colony. Bee World, 74: 5-19.

33. Fries I (2010). Nosema ceranae in European honey bees (Apis mellifera). J. Invertebr. Pathol, 103:S73-S79.

34. Fries I, Feng F, Silva AD, Slemenda SB, Pieniazek NJ (1996). Nosema ceranae n.sp. (Microspora, Nosematidae), morphological and molecular characterization of a microsporidian parasite of the Asian honey bee Apis cerana (Hymenoptera, Apidae). European Journal of Protistology, 32: 356-365.

35. Fries I, Slemenda SB, Silva A, Pieniazek NJ (2003). African honeybees (Apis mellifera scutellata) and nosema (Nosema apis) infections. J Apicul Res, 42, 13-15.

36. Gajger IT, Petrinec Z, Pinter L, Kozarić Z (2009). Experimental Treatment of Nosema Disease with "Nozevit" Phyto-pharmacological Preparation. Apicultural Research, 485-490.

37. Giersch T, Berg T, Galea F, Hornitzky M (2009). Nosema ceranae infects honey bees (Apis mellifera) and contaminates honey in Australia, Apidologie, 40:117-123.

38. Gisder S, Hedtke K, Möckel N, Frielitz MC, Linde A, Genersch E (2010a). Five-year cohort study of Nosema spp. in Germany: does climate shape virulence and assertiveness of Nosema ceranae? Appl. Environ. Microbiol., 76:30323038.

39. Gisder S, Möckel N, Linde A, Genersch E (2011). A cell culture model for Nosema ceranae and Nosema apis allows new insights into the life cycle of these important honey bee-pathogenic microsporidia. Environ. Microbiol, 13(2):404-413.

40. Gisder S, Schüler V, Horchler LL, Grot HD, Genersch E (2017). Long-Term Temporal Trends of Nosema spp. Infection Prevalence in Northeast Germany: Continuous Spread of Nosema ceranae, an Emerging Pathogen of 
Honey Bees (Apis mellifera), but No General Replacement of Nosema apis. Front Cell Infect.Microbiol., 7:301.

41. Graaf DC, Sabbe HR, De Rycke PH, Jacobs FJ (1994). Early development of Nosema apis (Microspora: Nosematidae) in the Midgut Epithelium of the Honeybee (Apis mellifera). J. Invertebr. Pathol, 63:74-81.

42. Guerrero-Molina C, Correa-Benítez A, Hamiduzzaman MM, Guzman-Novoa E (2016). Nosema ceranae is an old resident of honey bee (Apis mellifera) colonies in Mexico, causing infection levels of one million spores per bee or higher during summer and fall. J. Invertebr. Pathol., 141:38-40.

43. Guzman-Novoa E, Correa-Benitez A, Eccles L, Calvete Y, Mcgowan J, Kelly PG (2010). Varroa destructor is the main culprit for the death and reduced populations of overwintered honey bee (Apis mellifera) colonies in Ontario, Canada. Apidologie, 41(4): 443-450.

44. Haddad NJ (2014). First detection of Nosema ceranae in Jordan. European Scientific Journal 10(33), ISSN: 1857 7881 (Print) e- ISSN 1857- 7431.

45. Higes M, García-Palencia P, Martín-Hernández R, Meana A (2007). Experimental infection of Apis mellifera honeybees with the Microsporidia Nosema ceranae, J. Invertebr. Pathol, 94: 211-217.

46. Higes M, Martin-Hernandez R, Botias C, Bailon EG, Gonzalez-Porto AV, Barrios L, Del Nozal DJ, Bernal JL, Jimenez JJ, Palencia PG, Meana A (2008a). How natural infection by Nosema ceranae causes honeybee colony collapse.Environ. Microbiol., 10:2659-2668.

47. Higes M, Martin-Hernandez R, Meana A (2006). Nosema ceranae, a new microsporidian parasite in honey bees in Europe. J. Invertebr. Pathol. 92:93-95.

48. Higes M, Nozal MJ, Alvaro A, Barrios L, Meana A, Martin-Hernandez R, Bernal J (2011). The stability and effectiveness of fumagillin in controlling Nosema ceranae (Microsporidia) infection in honey bees (Apis mellifera) under laboratory and field conditions. Apidologie, 42:364-377.

49. Higes M., Martin-Hernandez R, Meana A (2010). Nosema ceranae in Europe: an emergent type $\mathrm{C}$ nosemosis, Apidologie, 41:375-392

50. Huang $Z$ (2012). Effects of Nosema on honey bee behavior and physiology. Available online: http:// articles.extension.org/pages/60674/effects-of-nosemaon-honey-bee-behaviour-and=physiology (accessed 03.11.19)

51. Huang Q, Kryger P, Le Conte Y, Moritz RF (2012). Survival and immune response of drones of a Nosemosis tolerant honey bee strain towards Nosema ceranae infections. J Invertebr Pathol, 109: 297-302.

52. Huang WF, Solter LF, Yau PM, Imai BS (2013), Nosema ceranae escapes fumagillin control in honey bees. PLoS Pathog, 9: e1003185.

53. Invernizzi C, Abud C, Tomasco IH, Harriet J, Ramallo G, Campa J, Katz H, Gardiol G, Mendoza Y (2009), Presence of Nosema ceranae in honeybees (Apis mellifera) in Uruguay. J Invertebr Pathol. 101(2):150-153.
54. Kang YB, Kim DS, Jang DH (1976), Experimental studies on the pathogenicity and developmental stages of Nosema apis. Korean J Vet Res, 16:11-25.

55. Kieliszek M, Piwowarek K, Kot AM, Błażejak S, ChlebowskaŚmigiel A, Wolska I (2018), Pollen and bee bread as new health-oriented products: A review, Trends in Food Science \& Technology, 71:170-180.

56. Klee J, Besana AM, Genersch E, Gisder S, Nanetti A, Tam DQ, Chinh TX, Puerta F, Ruz JM, Kryger P, Message D, Hatjina F, Korpela S, Fries I, Paxton RJ (2007), Widespread dispersal of the microsporidian Nosema ceranae, an emergent pathogen of the western honey bee, Apis mellifera. J. Invertebr. Pathol. 96, 1-10.

57. Li W, Chen Y, Cook SC (2018). Chronic Nosema ceranae infection inflicts comprehensive and persistent immunosuppression and accelerated lipid loss in host Apis mellifera honey bees. Int J Parasitol, doi:10.1016/j. ijpara.2017.11.004.

58. Lotfi A, Jamshidi R, Shahryar HA, Yousefkhani M (2009). The Prevalence of Nosemosis in Honey Bee Colonies in Arasbaran Region (Northwestern Iran), AmericanEurasian J. Agric. \& Environ. Sci., 5 (2): 255-257.

59. Mărghitaș LA (2017). Albine și produsele lor. (3th ed.). Editura Ceres București, (pp. 280-331), ISBN 978-973-401122-3.

60. Martinez J, Leal G, Conget P (2012). Nosema ceranae an emergent pathogen of Apis mellifera in Chile. Parasitol Res., 111(2):601-607.

61. Martin-Hernandez R, Bartolom C, Chejanovsky N, Le Conte Y, Dalmon A, Dussaubat C, Garcia-Palencia P, Meana A, Pinto MA, Soroker V, Higes M (2018). Nosema ceranae in Apis mellifera: a 12 years postdetection perspective, Environmental Microbiology, 20(4):1302-1329.

62. Martin-Hernandez R, Botias C, Barrios L, MartinezSalvador A, Meana A, Mayack C, Higes M (2011). Comparison of the energetic stress associated with experimental Nosema ceranae and Nosema apis infection of honeybees (Apis mellifera). Parasitol Res, 109: 605-612.

63. Martín-Hernández R, Botías C, Garrido-Bailón E, Martínez-Salvador A, Prieto L, Meana A, Higes M (2012). Microsporidia infecting Apis mellifera: coexistence or competition. Is Nosema ceranae replacing Nosema apis? Environ. Microbiol, 14:2127-2138.

64. Martin-Hernandez R, Meana A, Prieto L, Salvador AM, Garrido-Bailon E, Higes M (2007). Outcome of colonization of Apis mellifera by Nosema ceranae.Appl. Environ. Microbiol., 73:6331-6338.

65. Mayack C, Naug D (2013). Individual energetic state can prevail over social regulation of foraging in honeybees. Behav Ecol Sociobiol, 67: 929-936.

66. McCowen MC, Callender ME, Lawlis JF (1951). Fumagillin (H-3), a new antibiotic with amebicidal properties. Science, 113: 202-203.

67. McGowan J, De la Mora A, Goodwin PH, Habash M, Hamiduzzaman MM, Kelly PG, Guzman-Novoa E (2016). Viability and infectivity of fresh and cryopreserved Nosema ceranae spores. J Microbiol Methods, 131: 16-22. 
68. Mederle N, Lobo ML, Morariu S, Morariu F, Darabus G, Mederle O, Matos O (2018). Microscopic and Molecular Detection of Nosema ceranae in Honeybee Apis mellifera L. from Romania, REV.CHIM.(Bucharest), 69(12):37613772 .

69. Mitrea IL (2011). Parazitologie si boli parazitare la animale. Ed. Ceres, Bucharest.

70. Mutinelli F (2003). Practical application of antibacterial drugs for the control of honey bee diseases, Apiacta 2.

71. Muz MN, Girisgin AO, Muz D, Aydin L (2010). Molecular detection of Nosema ceranae and Nosema apis infections in Turkish apiaries with collapsed colonies. J Apic Res. 49(4):342.

72. Nanetti A, Rodriguez-Garcia C, Meana A, MartinHernandez R, Higes M (2015). Effect of oxalic acid on Nosema ceranae infection. Res Vet Sci, 102: 167-172.

73. Odemer R, Nilles L, Linder N, Rosenkranz P (2018). Sublethal effects of clothianidin and Nosema spp. on the longevity and foraging activity of free flying honey bees, Ecotoxicology, https://doi.org/10.1007/s10646-0181925-5.

74. Odnosum HV (2017). Distribution of the Nosema ceranae (Microspora, Nosematidae) in the apiaries in Ukraine. Vestnik zoologii, 51(2):161-166.

75. Papini R, Mancianti F, Canovai R, Cosci F, Rocchigiani G, Benelli G, Canale A (2017). Prevalence of the microsporidian Nosema ceranae in honeybee (Apis mellifera) apiaries in Central Italy. Saudi J Biol Sci., 24(5):979-982.

76. Paxton RJ (2010). Does infecton by Nosema ceranae cause "Colony Collapse Disorder" in honey bees (Apis mellifera)? J Apic Res, 49: 80-84.

77. Paxton RJ, Klee J, Korpela S, Fries I (2007). Nosema ceranae has infected Apis mellifera in Europe since at least 1998 and may be more virulent than Nosema apis. Apidologie, 38: $558-565$

78. Pohorecka K (2004). LABORATORY STUDIES ON THE EFFECT OF STANDARDIZED Artemisia absinthium L. EXTRACT ON Nosema apis INFECTION IN THE WORKER Apis mellifera, Journal of Apicultural Science, 42(2):131136.

79. Porrini MP, Garrido PM, Gende LB, Rossini C, Hermida L, Marcángeli JA, Eguaras MJ (2017). Oral administration of essential oils and main components: Study on honey bee survival and Nosema ceranae development, Journal of Apicultural Research, 56(5):616-624.

80. Ptaszyñska AA, Borsuk G, Anusiewicz M MuEnko W (2012). Location of Nosema spp. spores within the body of the honey bee. Med. Weter, 68 (10): 618-621.

81. Ptaszyńska AA, Borsuk G, Zdybicka-Barabas A, Cytryńska M, Małek W (2016). Are commercial probiotics and prebiotics effective in the treatment and prevention of honeybee nosemosis C?, Parasitol Res, 115:397-406.

82. Ptaszyńska AA, Trytek M, Borsuk G, Buczek K, RybickaJasińska K, Gryko D (2018). Porphyrins inactivate Nosema spp. microsporidia, Scientific Reports, 8:5523 DOI:10.1038/s41598-018-23678-8.
83. Şapcaliu A, Savu V, Radoi I, Tapaloagă D, Petruţ T, Victor C (2017). Evaluation of results in research made in order to obtain a phytotherapeutic product for the prophylaxis and fight against Nosema in bees The EuroBiotech, 1(1):39-43.

84. Simeunovic P, Stevanovic J, Cirkovic D, Sonja R, Lakic N, Stanisic L, Stanimirovic Z (2014). Nosema ceranae and queen age influence the reproduction and productivity of the honey bee colony. J Apic Res, 53: 545-554.

85. Sina M, Alastair G, Farmer M, Andersen R, Anderson O, Barta J, Bowser S, Brugerolle G, Fensome R, Fredericq S, James T, Karpov S, Kugrens P, Krug J, Lane C, Lewis L, Lodge J, Lynn D, Mann D, Maccourt R, Mendoza L, Moestrup O, Mozley S, Nerad T, Shearer C, Smirnov A, Spiegel F, Taylor M (2005). The new higher level classification of Eukaryotes with emphasis on the taxonomy of Protists. Journal of Eukaryotic Microbiology, 52: 399-451.

86. Stevanovic J, Stanimirovic Z, Genersch E, Kovacevic Sr, Ljubenkovic J, Radakovic M, Aleksic N (2011). Dominance of Nosema ceranae in honey bees in the Balkan countries in the absence of symptoms of colony collapse disorder. Apidologie, 42:49-58.

87. Suwannaponga G, Maksonga S, Phainchajoenb M, Benbowc ME, Mayackd C (2018). Survival and health improvement of Nosema infected Apis florea (Hymenoptera: Apidae) bees after treatment with propolis extract, Journal of Asia-Pacific Entomology, 21:437-444.

88. Szawarski N, Saez A, Domínguez E, Dickson R, De Matteis Á, Eciolaza C, Justel M, Aliano A, Solar P, Bergara I, Pons C, Bolognesi A, Carna G, Garcia W, Garcia O, Eguaras M, Lamattina L, Maggi M, Negri P (2019). Effect of Abscisic Acid (ABA) Combined with Two Different Beekeeping Nutritional Strategies to Confront Overwintering: Studies on Honey Bees'Population Dynamics and Nosemosis, Insects, 10(329):1-14.

89. Tapaszti Z, Forgach P, Kovago C, Bekesi L, Bakonyi T, Rusvai M (2009). First detection and dominance of Nosema ceranae in Hungarian honeybee colonies. Acta Vet Hung, 57(3): 383-388.

90. Teixeira EW, Santos LG, Sattler A, Message D, Alves ML, Martins MF, Grassi-Sella ML, Francoy TM (2013). Nosema ceranae has been present in Brazil for more than three decades infecting Africanized honey bees. J. Invertebr. Pathol., 114(3):250-254.

91. Traver BE, Fell RD (2011). Prevalence and infection intensity of Nosema in honey bee (Apis mellifera L.) colonies in Virginia. J. Invertebr. Pathol., 107(1):43-49.

92. Tritschler M, Retschnig G, Yanez O, Williams GR, Neumann P (2017). Host sharing by the honey bee parasites Lotmaria passim and Nosema ceranae. Ecol Evol. 15,7(6):1850-1857.

93. Underwood RM, Currie RW (2009). Indoor winter fumigation with formic acid for control of Acarapis woodi (Acari: Tarsonemidae) and Nosema disease, Nosema sp. J Econ Entomol, 102: 1729-1736.

94. Utuk AE, Cigdem F, Ahmet P, Girisgin O, Selcuk O, Aydin L (2016). Microscopic and molecular detection of Nosema spp. in honeybees of Turkey. Apidologie, 47(2):267-271.

95. van den Heever JP, Thompson TS, Curtis JM, Ibrahim A, Pernal SF (2014). Fumagillin: an overview of recent 
scientific advances and their significance for apiculture. J Agric Food Chem, 62: 2728-2737.

96. van den Heever JP, Thompson TS, Otto SJG, Curtis JM, Ibrahim A, Pernal SF (2016a). Evaluation of Fumagilin-B and other potential alternative chemotherapies against Nosema ceranae-infected honeybees (Apis mellifera) in cage trial assays. Apidologie, 47: 617-630.

97. Vidau C, Diogon M, Aufauvre J, Fontbonne R, Vigue`s B, Brunet JL, Texier C, Biron DG, Blot N, El Alaoui H, Belzunces LP, Delbac F (2011). Exposure to sublethal doses of fipronil and thiacloprid highly increases mortality of honeybees previously infected by Nosema ceranae. PLoS One, 6: e21550.

98. Vidau C, Panek J, Texier C, Biron DG, Belzunces LP, Le Gall M, Broussard C, Delbac F, El Alaoui H (2014). Differential proteomic analysis of midguts from Nosema ceranaeinfected honeybees reveals manipulation of key host functions. J Invertebr Pathol,121: 89-96.

99. Whitaker J, Szalanski AL, Kence M (2011). Molecular detection of Nosema ceranae and N. apis from Turkish honey bees. Apidologie 42:174-80.
100. Williams GR, Shafer ABA, Rogers REL, Shutler D, Stewart DT (2008a). First detection of Nosema ceranae, a microsporidian parasite of European honey bees (Apis mellifera), in Canada and central U.S.A. Journal of Invertebrate Pathology, 97: 189-192.

101. Williams GR, Shutler D, Little CM, Burgher-Maclellan KL, Rogers REL (2010a). The microsporidian Nosema ceranae, the antibiotic Fumagilin-B $\mathrm{B}$, and western honey bee (Apis mellifera) colony strength. Apidologie 42: 15-22.

102. Williams GR, Shutler D, Little CM, Burgher-Maclellan KL, Rogers REL (2011). The microsporidian Nosema ceranae, the antibiotic Fumagilin-BVR, and western honey bee (Apis mellifera) colony strength. Apidologie, 42: $15-22$.

103. Yoshiyama M, Kimura K (2011). Distribution of Nosema ceranae in the European honeybee, Apis mellifera in Japan. J. Invertebr.Pathol., 106(2):263-267.

104. Zander E (1909). Tierische Parasiten als Krankheitserreger bei der Biene. Münchener Bienenzeitung 31: 196-204. 